\title{
The Language of Honours
}

This chapter discusses typical language patterns in Delphic honorific documents (decrees and tituli honorarii) and their evolution over time, with a special focus on abbreviated decrees as Delphi's special contribution to Greek epigraphic culture. Before proceeding to discuss these issues, however, it is important to stress that documents analysed within this chapter comprise only those found within the Delphic temenos and issued by the Delphic polis. Documents set up in Delphi by foreign communities will be discussed only in passing, as they represent foreign epigraphic traditions and formulae. Occasionally, I will consider certain decrees bestowed outside of Delphi as comparanda, but mainly by juxtaposing Delphic abbreviated decrees with foreign-issued abbreviated decrees in order to highlight innovations and idiosyncrasies in the Delphic epigraphic tradition.

The process of granting honours is well known from the Athenian texts, the fundamentals of the process being similar across all Greek poleis. ${ }^{1}$ Customarily, a motion was put forward to the decision-making body and voted on; if the motion passed, then a decree was produced, summarising the contents of the motion in its motivation part. Once bestowed, honours were communicated to posterity through the medium of inscriptions. ${ }^{2}$ A careful reading of the preserved decrees reveals an enormous number of local variations in epigraphic patterns, which complicates any attempt to read coherent frameworks into this material. To fully unpack the Delphic language of honours, I will start my analysis by considering the standard formulae of Delphic honorific decrees. ${ }^{3}$

\subsection{The Formulae of Delphic Honorific Decrees and the Phenomenon of Delphic Abbreviated Decrees}

\subsubsection{Abbreviated Decrees ${ }^{4}$}

The majority of inscribed decrees at Delphi come in the so-called abbreviated form (c. 790 decrees in total). Abbreviated decrees, a local epigraphic

1 Osborne 2012, 34-41.

2 Gengler 2017, 38. See Gauthier 1985, 83-92; Rhodes and Lewis 1997; Osborne 2012, 33-59. The procedure of voting and proclaiming tituli honorarii was similar, see Biard 2017, 19-27.

3 For standard patterns in the Athenian decrees, see Henry 1983.

4 My findings concerning the formulae of the Delphic abbreviated decrees have been published in ZPE 2013, 157-162.

(C) DOMINIKA GRZESIK, 2021 | DOI:10.1163/9789004502499_007

This is an open access chapter distributed under the terms of the CC BY-NC 4.o license.ka Grzesik - 9789004502499 
phenomenon attested in certain areas of central and northern Greece, on the Greek islands, and in parts of Asia Minor and the Pontic colonies, has not drawn the amount of scholarly attention previously devoted to full decrees. ${ }^{5}$ Swodoba, the first scholar to use the term 'abbreviated decree' (abgekürzte Dekrete), defined such documents as decrees that omit parts of the standard formulae. ${ }^{6}$ Rhodes in turn succinctly presented the catalogue of Delphic decrees but devoted only two and a half pages to abbreviated decrees, his brief account not quite capturing the local importance of this decree type. ${ }^{7}$ Finally, Musielak in her study of the Delphic polis discussed only the development and evolution of full pattern decrees. ${ }^{8}$ In light of these omissions, this chapter aims to offer a comprehensive examination of Delphic abbreviated decrees in all their complexity.

Having read and analysed over 790 abbreviated decrees from Delphi, I must note that no fixed and final formula existed for this type of honorific document; nevertheless, no less than 425 Delphic abbreviated decrees represent a single predominant type that displays most of their characteristics. In the Delphic context, an abbreviated decree is a document issued by a decision-making body, the text of which contains four core elements: (1) the name of the body that issued the decree; (2) a verb specifying the action(s) agreed upon by the body; (3) the name of the recipient(s) of honours; and (4) the list of granted honours. Such a decree might also include additional elements, such as an invocation, an enumeration of descendants/relatives of the honorand, ${ }^{9}$ and/or the dating formula. An abbreviated decree, however, as a rule omits elements that are essential in full decrees, such as the enactment formula (हैंठ the formula of the proposer of a motion ( $\varepsilon i \pi \varepsilon v /$ 'said'), the motivation clause

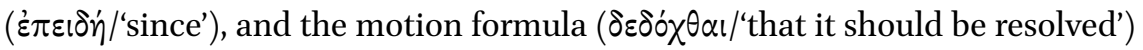
or closing formulae. ${ }^{10}$

$5 \quad$ Larfeld 1914, 329-333; Nawotka 2014, 59.

6 Swoboda $1890,47$.

7 Rhodes and Lewis 1997, 126-140.

8 Musielak 1989, 68.

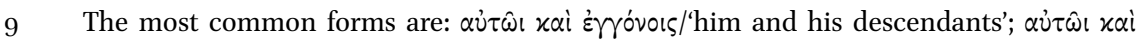

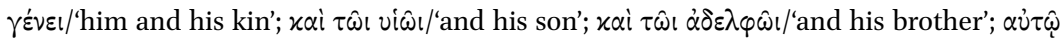

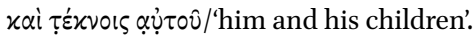

10 Nonetheless, the motivation clause does appear in fourteen abbreviated decrees. $F d D$ 3.338 (11-1 BCE) is neither an abbreviated nor a full decree: it opens with the standard formula attested in Delphic abbreviated decrees but subsequently includes elements more typical of full pattern documents (namely, the motivation clause and a variation of the enactment formula). 
It is useful to quote in full what might be considered a typical case of a Delphic abbreviated decree from the Hellenistic period:

$F d D 1.26$ (mid-third century вСЕ)

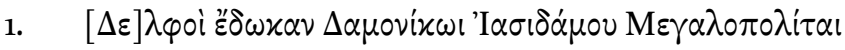

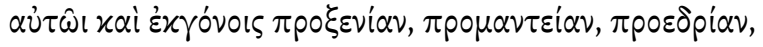

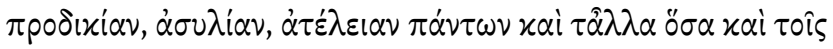

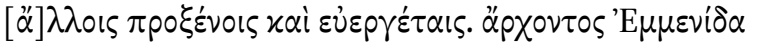

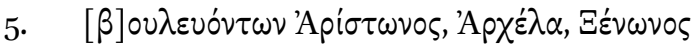

The Delphians gave Damonikos, son of Iasidamos from Megalopolis him and his descendants proxenia, promanteia, proedria, prodikia, asylia, ateleia and he is to have everything else that is given to other proxenoi and euergetai. when Emmenidas was archon, when Ariston, Archelas, Xenon were councilors.

Let us now discuss the core elements of Delphic abbreviated decrees in some detail:

1) The name of the body that issued the decree: the most common form of the body that passed the decree is $\Delta \varepsilon \lambda \varphi \circ \mathrm{i} /$ 'the Delphians';11 other variations, however, occasionally appear. ${ }^{12}$

2) A verb specifying the action(s) agreed upon by the body: most frequently,

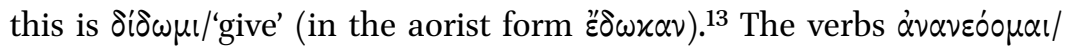
'renew' and $\alpha \pi \circ \delta i \delta \omega \mu \mathrm{l} /$ 'restore or renew' appear in decrees that renew honours which were previously bestowed, ${ }^{14}$ while $\pi \circ$ ó $\omega /$ 'make' features

11 E.g. $F d D$ 1.135, $F d D$ 1.142, $F d D$ 1.177-179, $F d D$ 1.185, $F d D$ 1.203, FdD 1.207, FdD 1.212-213, $F d D$ 1.225, $F d D$ 1.235, FdD 1.237, FdD 2.101, FdD 2.107, FdD 1.391, FdD 1.395, FdD 1.416, FdD 1.419-420, FdD 1.425, FdD 1.437[2], FdD 1.438, FdD 1.445, FdD 2.210, FdD 3.195-199, FdD 3.379, FdD 4.376-377, FdD 4.384-385, FdD 4.388, FdD 4.390-392; SGDI 4747; BCH 23.1899.535,20[2], $B C H$ 66/7.1942/3.133; SEG 50.617.

$12 \dot{\alpha} \pi \dot{\partial} \lambda{ }_{1 \varsigma} \tau \hat{\omega} \nu \Delta \varepsilon \lambda \varphi \hat{\omega} \nu /$ the city of the Delphians' FdD 4.406, FdD 4.411 II; SGDI 2607; $\dot{\eta}$

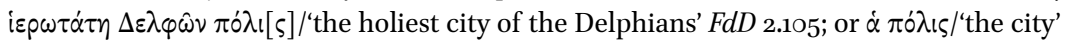
FdD 4.396.

13 E.g. $F d D$ 1.135, $F d D$ 1.142, $F d D$ 1.439, $F d D$ 3.379, $F d D$ 4.382; SGDI 4747; $B C H$ 23.1899.535,20 [2], BCH 66/7.1942/3.133; SEG 50.617.

$14 F d D$ 1.13, $F d D$ 1.16, $F d D$ 1.24[2], $F d D$ 1.38, $F d D$ 1.6o, $F d D$ 1.86[2], $F d D$ 1.197, $F d D$ 1.356, $F d D$ 1.359, $F d D$ 1.442, FdD 2.193, FdD 4.20, FdD 4.403 III.1, FdD 4.406, FdD 4.419; SGDI 2600 . 
in grants of citizenship and/or bouleuteia. ${ }^{15}$ Other rare variations include $\tau i \mu \dot{\alpha} \omega /$ /honour'16 and $\chi \alpha \rho i \zeta \omega /$ 'gratify'. ${ }^{17}$

3) The name of the recipient(s) of honours: Delphic abbreviated decrees render the recipient of gifts in the dative or the accusative. The following verbs name the honorand in the dative: $\delta \delta \delta \omega \mu / /$ 'give,', ${ }^{18} \chi \alpha \rho i \zeta \omega /$ 'gratify,', ${ }^{19}$

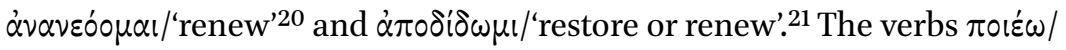
'make'22 and $\tau \mu \alpha \alpha \omega /$ 'honour'23 render the name of the recipient in the accusative.

4) The list and ordering of honours: although it has already been discussed in Chapter 2 and in Bouvier's article, at this point one should note that the bulk of Delphic abbreviated decrees of the Hellenistic period open with a grant of proxenia. ${ }^{24}$ In addition to proxenia, by far the most common awards at Delphi comprised grants of promanteia, proedria, ateleia, prodikia and asylia. With the subjections of Delphi to Rome and the establishment of a new order by Augustus, proxenia lost its functional paradigm and the format of the Delphic proxeny decrees was altered to reflect this; subsequently, grants of citizenship and bouleuteia became the most frequently voted gifts at Delphi. ${ }^{25}$

My analysis of the most frequently attested type of Delphic abbreviated decrees demonstrates that their formula remained flexible. ${ }^{26}$ Nevertheless, as Henry accurately observed, consistency in the text of the decree was not expected. ${ }^{27}$ As long as such inscriptions provided the essential information, consistency was not demanded. In other words, every single decree, even an abbreviated one, is unique. The following example reveals the simplest version of Delphic abbreviated decree:

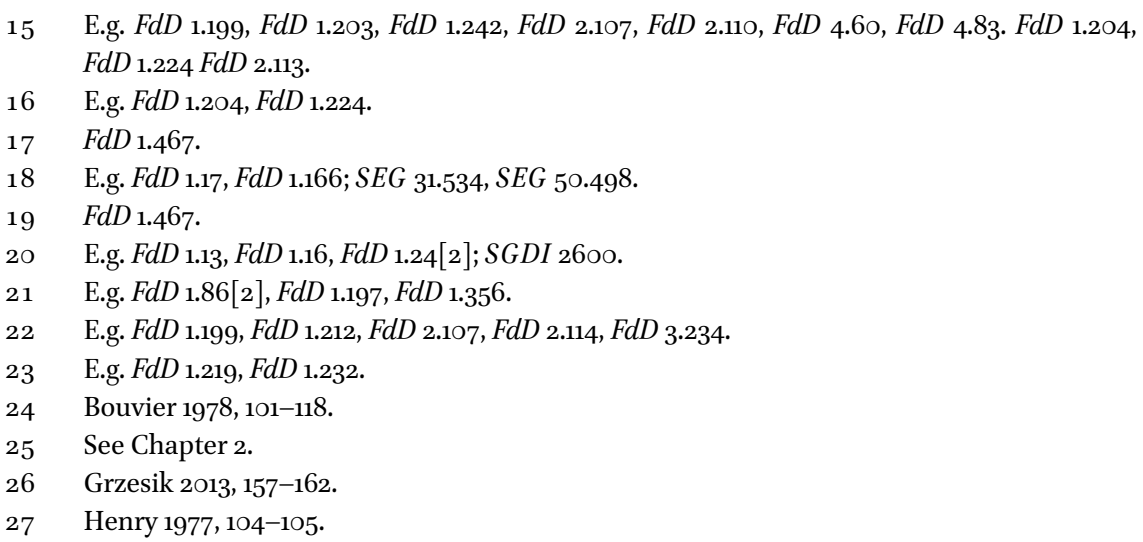




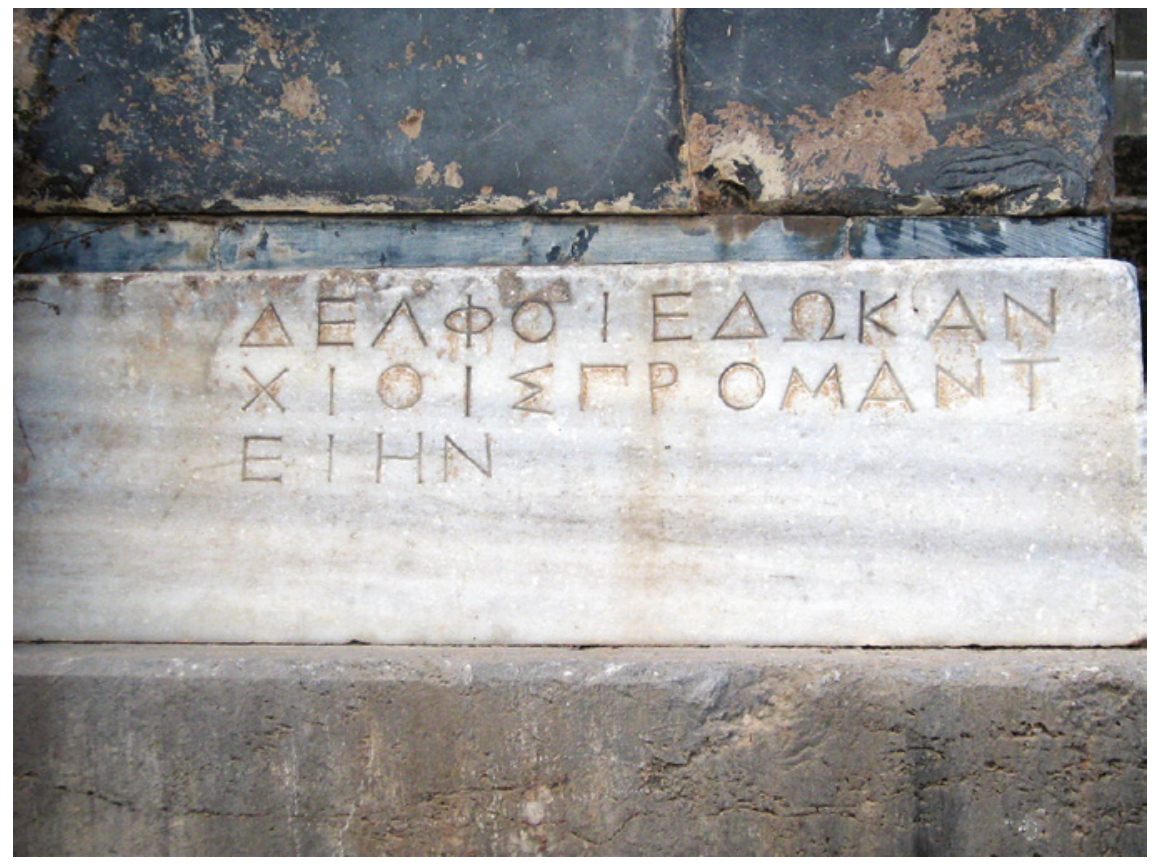

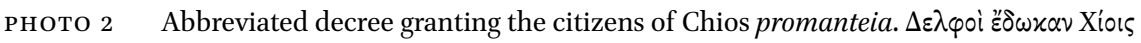

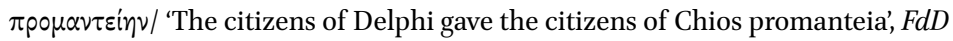
3.213 (fourth/third century BCE). (Archaeological site of Delphi. The inscription is under the protection of the Ephorate of Antiquities of Phocis.)

(C) THE HELLENIC MINISTRY OF CULTURE AND SPORTS/ ARCHAEOLOGICAL RESOURCES FUND

This part of my analysis intends to stress the inherent complexity of abbreviated decrees at Delphi, by analysing their formulaic structure and, first and foremost, by highlighting how exceptional they were. The majority of scholars, including Rhodes, expressed no interest in Delphic decrees in general and abbreviated decrees in particular, regarding them as mere abridgements of regular decrees. ${ }^{28}$ The assembled material, however, testifies to the exceptional popularity of abbreviated decrees at Delphi: for every preserved full decree at Delphi, we find four abbreviated ones, with almost $79 \%$ of all Delphic decrees being of the abbreviated kind. This highly unusual ratio has almost no parallel in other Greek poleis that are known to have issued abbreviated decrees: the full-abbreviated ratio amounts to 81 to 19 in Olbia (with 98 preserved decrees) ${ }^{29}$

28 Rhodes and Lewis 1997, 126-140.

29 Nawotka 2014, 6; 36-46; 65-69. 
and 6o to 40 in Gonnoi (Thessaly). ${ }^{30}$ Only the cities of the Aetolian League and Miletos have epigraphic records that show a predominance of abbreviated decrees similar to the one found at Delphi. ${ }^{31}$

Why did Delphi issue so many abbreviated decrees? One possible explanation is that it represents a local efflorescence of a common Hellenic habit. The majority of Delphic abbreviated decrees were inscribed on buildings and not on free standing stelai. ${ }^{32}$ The habit of engraving the texts of public decrees on building-walls has numerous known parallels in Greece, particularly concerning the documentary activity of smaller cities. Arkesine on Amorgos and Megara habitually published proxeny decrees on walls; Siphnos inscribed them on the walls of the shrines of Apollo Pythios;3 the citizens of Oropos carved their proxeny decrees onto honorific statue bases. ${ }^{34}$ Liddel goes even further by claiming that, "[i]f we look beyond the publication of proxeny awards, the habit of writing state ordinances on walls is known from more prolific cities, in shape of the wall of the Stoa Basileus in the Athenian agora, or the inscribed law codes of Drerus (ML 2) or Gortyn (ML 41), or the wall containing the edicts of Alexander at Priene. ${ }^{35}$ Using walls as inscription surfaces, an old Greek habit, became enormously popular in Delphi, where the spread of the epigraphic culture has close ties with the erection of the first treasuries, their walls later being used as a 'writing surface. ${ }^{36}$

In my view, four main reasons can be given to account for the use of monument bases and building walls as the epigraphic medium. First, writing a decree on a wall ensures that an inscribed enactment will remain visible as long as the building stands and the cuts remain deep, whereas decrees inscribed on free-standing stelai often suffer from destruction, loss or displacement of their host medium. Second, building walls may have restricted the space required for full decrees and may therefore have required the communities to limit the inscribing of such decisions to a more concise format. In this connection we may also note that Delphic full pattern decrees were on average shorter than their Athenian equivalents. Inscribing decrees in the abbreviated form instead of the full pattern hence provides an opportunity to honour more people for

\footnotetext{
$30 \quad$ Gonnoi II; Rhodes and Lewis 1997, 169-170.

31 For the Aetolian abbreviated decrees at Thermon, see $I G{\mathrm{IX}, 1^{2}}{ }^{1-5}$ O; for Miletos, see Nawotka 2014, 5 ; 22-36; 6o-65.

32 Chapter 6. For the reasoning behind inscribing decrees in Athens, see Lambert 2011, 193-214.

33 Liddel 2009, 428-433; Papazarkadas 2013, 187.

34 Wilding 2015, 67-69.

35 Liddel 2009, 432.

$36 \quad$ Chapter 1.
} 
a longer period of time, which particularly mattered at Delphi where decrees were produced not randomly but on a mass scale. As both popular and space-saving, Delphic abbreviated decrees appear in the epigraphic record between the fourth century ВСE and the end of the second century CE, with no recorded interruptions.

Third, the lack of available epigraphic space at Delphi may explain why the Delphians preferred abbreviated decrees to full pattern decrees. The relatively small holy precinct of Apollo at Delphi had to accommodate honorific documents, texts of manumission records, hundreds of monumental dedications, and private and public portraits of honours dedicated by the Delphians, the Amphictyonic League and other communities. Thus, Delphi at the beginning of the Hellenistic period suffered from epigraphic congestion and free space was hard to come by. ${ }^{37}$ Since I discuss the issue of epigraphic space in detail in Chapter 6, at this point it suffices to say that - in contrast to the traditional epigraphic medium of stelai - walls, statue bases and massive square pillars had two or even four inscribable sides. Prioritising these cost-effective media allowed the Delphians to fully exploit the available material and space without adding clutter.

Fourth, inscribing monument bases and building walls cost less than the erection of stelai. To consider an example from another polis, Mack argues that the parsimony of the Oropians drove them to inscribe statue bases in lieu of more expensive media. ${ }^{38}$ Here, one needs to note that the mass production of honorary decrees at Delphi must have incurred extreme costs. As a useful comparandum, a third-century BCE text from Delos records the cost of an inscription engraved on a stela: 25 drachmas for stone; one drachma and three obols for stone transport; 100 drachmas for engraving (one drachma for every 3 oo letters), five drachmas for lead, one drachma for wood, two drachmas and three obols for raising, making a total of 135 drachmas. ${ }^{39}$ Inscribing building walls instead of stelai obviated the costs of material, transport, and erection, while the abbreviated form minimised the cost of engraving. Finally, the role that cutters played with regard to making stone decrees must be considered. According to Tracy's estimates, fifteen to twenty engravers inscribed decrees on stelai in Athens between 200 and 160 BCE and twice this number between 140 and 100 BCE. ${ }^{40}$ Bearing this in mind, one can conjecture that Delphi

Elsewhere I have argued that the congestion in the Delphic sacred precinct forced both the Macedonians and the Aetolians to display their honorific monuments in the northern and western regions of the sanctuary, Grzesik 2018a, 33-36.

38 Mack 2015, 238. Pace Mack, Wilding 2015, 67-69.

39 IG XI,2 161A, l. 118-119. See Constantakopoulou 2017, 172.

40 Tracy 1990, 227. 
needed fewer engravers for inscribing abbreviated decrees and thus saved on their salaries.

One may argue that the case of Athens contradicts this argumentation, as in Athens decrees were also produced on the global scale; however, instead of being inscribed on the building walls, they were presented in full pattern on free-standing stelai. ${ }^{41}$ The Athenian city-state could sustain this output thanks to its extraordinary affluence and the numerous sites in which it housed thousands of stelai (the Akropolis, the agora, the sanctuary of Dionysus, or the Asklepieion). In contrast, Delphic honorific documents fought for limited space in the small temenos. ${ }^{42}$

To study the idiosyncrasies of the Delphic honorific habit opens up new research perspectives on Greek abbreviated decrees. Contrary to prevailing opinion, abbreviated decrees were not defective, truncated surrogates for full pattern texts; rather, as respected and valid documents, they succinctly imparted the essential information, i.e. the reasoning behind the decision to honour, the name of the honorand, and the honour itself. Although abbreviated decrees lack the enactment formula and the motivation clause, the short text always convey the crucial details. In contrast to engraving full pattern decrees on stelai, publishing abbreviated decrees on walls and statue bases avoided unnecessary expenditures and saved public space from overcrowding. Hence, Delphi's limited sanctuary space and the growing pressure to thank the city's benefactors with decrees shows why abbreviated decrees became the favoured honorific decree in Delphi's epigraphic output.

\subsubsection{Full Pattern Decrees}

By their nature, Delphic full pattern decrees, were highly formulaic and fossilised in form. Their standardised and opaque language, however, often obfuscates the act that preceded the honour. Since it is nominally expressed in the motivation clause, honoured deeds hide behind the generic phrasing which is so typical for Greek honorific acts. In exceptional instances some texts specify the commended deed, just as the expanded decree patterns of Athens and certain communities of Asia Minor also provide their reader with details on rewarded benefactions. ${ }^{43}$

\footnotetext{
41 Osborne 2012, 33-59.

42 Chapter 6. Liddel 2003, 79-93; Shear 2007, 91-115.

43 Mack 2015, 24; Constantakopoulou 2017, 125. For the Athenian decrees, see Henry 1983; Lambert 2011, 193-214 and 2018. For decrees in Asia Minor, see Zuiderhoek 2009 and Nawotka 2014.
} 
The wording of the Delphic full decrees aligns (at least partially) with formulae used in other regions. As in Athens, so too in Delphi decrees refer to themselves as psephismata. ${ }^{44}$ What Delphic full pattern decrees shared with their Peloponnesian counterparts is their frequent omission of the section specifying the proposer of the motion. ${ }^{45} \mathrm{My}$ analysis of standard formulae used in the Delphic full pattern decrees reveals their other distinctive features, which will be specified below.

The bulk of Delphic full pattern decrees consist of the following elements:

- an invocation to the god(s) and/or good fortune

- the dating formula

- the nature of the meeting enacting the decree

- the name of the proposer of a motion

- the enactment formula

- the motion formula

- the motivation clause, and

- closing formula(e).

1) The vast majority of decrees either opens or ends with an invocation to the $\operatorname{god}(\mathrm{s})$ and/or good fortune. ${ }^{46}$

2) The dating formula, which specifies the Delphic officials in office at the time; most frequently this is the archon (an eponymous official at Delphi), ${ }^{47}$ the bouleutai and, occasionally, the secretary of the Delphic council (from the second century вСЕ onwards). ${ }^{48}$

3) The nature of the meeting enacting the decree is mentioned in 98 decrees (the third century вСЕ-the first half of the first century ВСЕ), and is specified

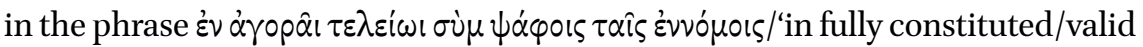
agora, with the number of votes required by laws'. Three decrees of the imperial period were enacted during the special meetings of the assembly $(\dot{\varepsilon} \nu \pi \rho \circ \sigma \alpha \lambda \dot{\eta} \tau \omega$

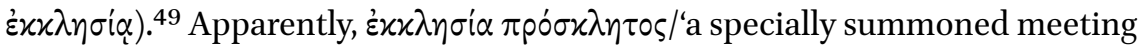

44 E.g. $F d D$ 1.466. See Larfeld 1914, 333; De Laix 1973, 87; McLean 2002, 222-223.

45 Liddel 2009, 423.

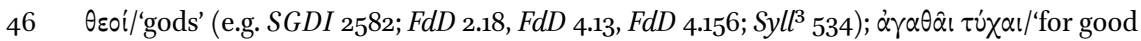
fortune' (e.g. $F d D$ 2.20, $F d D$ 1.151, $F d D$ 3.125, $F d D$ 1.354, $F d D$ 4.118) and other variations of these two forms.

47 Sherk 1990, 254-255; Davies 1998, 2.

48 Rhodes and Lewis claim that the number of bouleutai varied at Delphi. In the fourth century ВСE, fifteen bouleutai performed their duties at one time, and perhaps were grouped into committees of five; fifteen became five in the third century BCE and then three in the second century вСЕ. In the period $c$. 10о-6о вСЕ, four bouleutai were appointed, then three in the period c. 6о-4о вСE, and subsequently, only two. See Rhodes and Lewis 1997,135 .

FdD 4.47 (98 CE), FdD 4.61 (75-100 CE), FdD 4.63 (second century CE). 


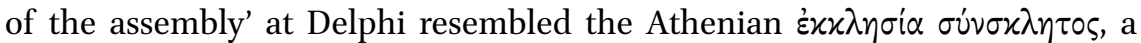
short-notice emergency meeting of the assembly.50 The three decrees record the erection of statues at Delphi for C. Caristanius Iulianus, Leukios Likinios Eukleides, and Sosandros, son of Pleistarchos. It remains unknown whether special assembly meetings took place only in the imperial period. Perhaps in the Hellenistic period the Delphic assembly met exclusively on a regular basis; the lack of further evidence, however, does not allow us to answer this question in a definitive manner.

4) The name of the proposer of a motion marks a divergence from the contemporary documentary practice at Athens or Delos. ${ }^{51}$ The full decrees at Delphi habitually do not name their proposers: the formula appears in only $3^{2}$ out of $c .217$ full pattern decrees (Appendix 5). Other communities whose decrees did not divulge the proposers of their motions include Megara and some cities in Arkadia and Achaia. ${ }^{52}$ In the case of Megara, Liddel conjectured that the absence of the name of the proposers in Megarian proxeny decrees limited opportunities for accruing political capital, unlike in Athens, where the proposer always appeared in the formula. Continuing this line of thought, Liddel speculated that it may suggest a less democratic mode of publishing enactments and made more difficult the attribution of responsibility to an individual proposer in Megara. ${ }^{53}$ The Delphic dataset reveals that the habit of inscribing the name of the proposer was rather associated with the Delphic epigraphic tradition of the second century вСE, not necessarily with the changes within the democratic system. As for the precise timing of this subset of documents, 21 out of 32 decrees which name their proposers come from the second century всE (nos. 2-22 in Appendix 5), while 16 out of these $3^{2}$ documents come from the brief period of 150-10о вСЕ. My earlier work on Delphic full decrees demonstrated that their formula lengthened in the second century BCE, when they contained the largest number of additional elements. Texts dating to this period included not only the proposer of the motion but also the publication clause and additional closing formulae. ${ }^{54}$

As for the identities of the proposers at Delphi, the material sample reveals that making proposals at Delphi was the prerogative of a small circle of active public officials. For example, four proposers acted as Delphic bouleutai (Appendix 5, nos. 11, 12, 18 and 25), whereas one motion names Emmenidas

\footnotetext{
50 Tracey 1988, 186-188; Hansen 2007, 271-306.

$51 \quad$ Rhodes and Lewis 1997, 27-29.

52 Rhodes and Lewis 1997, 492-493.

53 Liddel 2oo9, 423.

54 Grzesik 2018a, 23-42.
} 
served as a Delphic archon (Appendix 5, no. 23). Three sons of Diodoros (Appendix 5, nos. 9-12) with the names of Kallikrates, Mnasitheos and Antigenes were by far the most prolific proposers of Delphic decrees, putting forward no fewer than four motions in the period between 140-100 BCE. They were all involved in Delphic politics in the second half of the second century BCE: Antigenes served as an archon and a bouleutes, ${ }^{55}$ Kallikrates as an archon and a secretary of the Delphic council, ${ }^{56}$ and Mnasitheos as an archon. ${ }^{57}$ Interestingly, the honorands whose decrees they promoted came only from neighbouring communities: Thebes in Boeotia, ${ }^{58}$ Kierion in Thessalia, ${ }^{59}$ and Pherai in Achaia. ${ }^{60}$

A separate category of proposers encompasses foreign envoys who were sent to Delphi to settle issues of international interest before the Delphic assembly (Appendix 5, nos. 1, 2, 3, 5, 6, 15, 16 and 20). For instance, ambassadors from Sardis came to ask for the recognition of the new festival Panathenai-Eumeneia and the permission to add a horse competition to the games (Appendix 5 , nos. $5^{-6)} \cdot{ }^{61}$ In three instances, theoroi and ambassadors represented the interests of their own fellow citizens (Appendix 5, nos. 3, 15 and 16). In all cases the Delphic assembly granted the requested honours and privileges.

The examination of proposers of motions in detail allows us to track changes within the very pattern of Delphic full decrees. In the Hellenistic period, the standard formula equated to $\dot{\varepsilon} \pi \varepsilon i /$ 'since' + the name of the proposer $+\dot{\varepsilon} \pi \varepsilon \lambda \theta \dot{\omega} \nu$ $\dot{\varepsilon} \pi i \tau_{\alpha} \nu \dot{\varepsilon} \varkappa \varkappa \lambda \eta \sigma^{\prime} \alpha \nu \delta เ \varepsilon \lambda \dot{\varepsilon} \gamma \eta \dot{v} \pi \dot{\varepsilon} \rho /$ hhaving come upon the assembly, made a statement about'. Sometime between 55 and 25 BCE, the formula was shortened to include only the name of the proposer and $\varepsilon i \pi \varepsilon v /$ 'said'. This development occurred rather rapidly: a decree of $55-5$ О вCE conforms to the Hellenistic pattern (Appendix 5, no. 25), whereas the text dated to $30-25$ BCE establishes the new formula (Appendix 5, no. 27).

Finally, I wish to discuss two exceptional late decrees which specify names of their proposers (Appendix 5, nos. 31 and 32). Both decrees probably date to the same meeting of the Delphic assembly in July $129 \mathrm{CE}$. Their formulae, however, differ in some surprising ways:

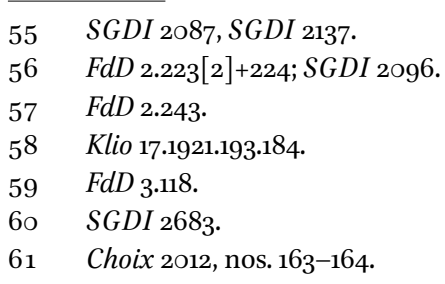


FdD 2.102

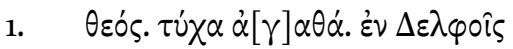

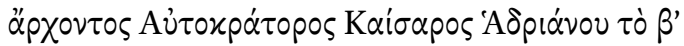

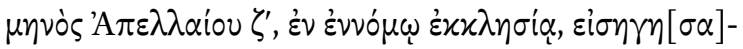

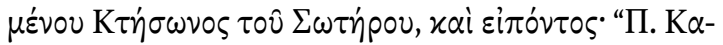

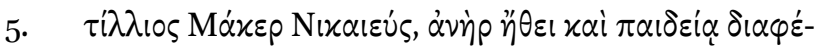

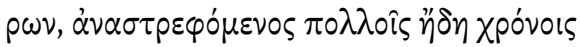

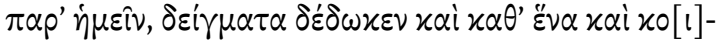

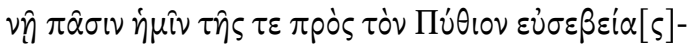

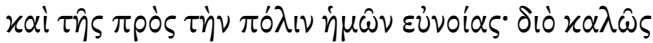

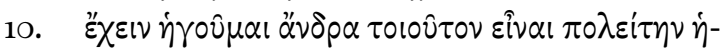

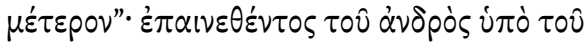

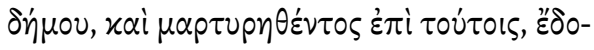

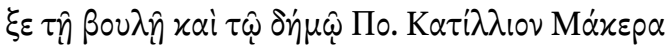

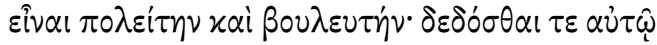

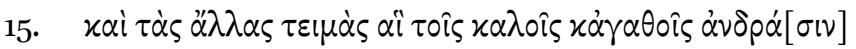

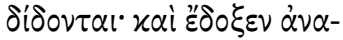

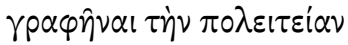

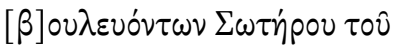

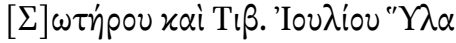

\section{God. Good fortune.}

When Emperor Caesar Hadrian was archon in Delphi for the second time In the sixth day of the month Apellaios, in a legitimate assembly, when Kteson, son of Soteros, proposed and said: "P. Catillius Macer from

Nikaia, a man excelling in manners and education

living among us for a long time,

has given an exhibitions of piety to people both individually and

collectively

pious towards (the Apollo) Pythios, and of good disposition towards our city.

Therefore, I command to make this noble man our fellow-citizen,

so that he be praised by the people and that everyone will witness that."

It was resolved by the council and the people

that P. Catillius Macer is citizen and councillor,

and he is to have everything else that is given to other noble men.

It was also resolved to inscribe the citizenship.

When Soteros, son of Soteros and Tib. Iulius Hylas were councilors. 


\author{
FdD 2.103

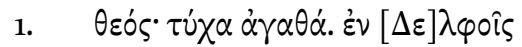

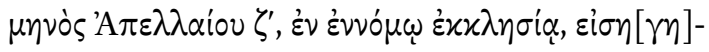

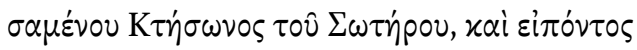

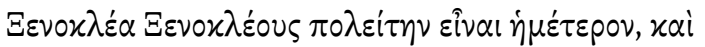

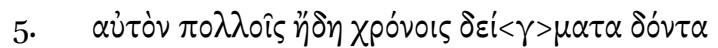

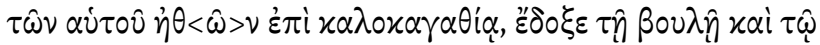

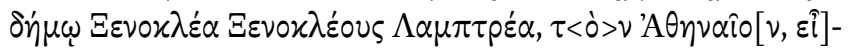

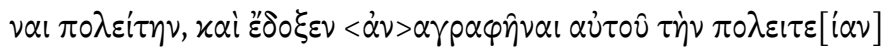

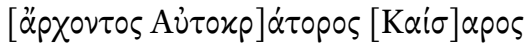

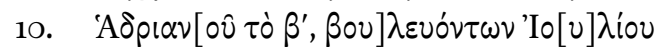

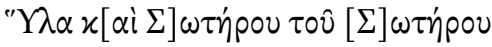

God. Good fortune

In Delphi, in the sixth day of the month Apellaios, in a legitimate assembly, when Kteson, son of Soteros, proposed and said that

Xenokles, son of Xenokles should be our fellow-citizen and that many times he has already given exhibitions of his leaning toward nobleness.

It was resolved by the council and the people

that Xenokles, son of Xenokles, an Athenian from the deme Lamptrai is citizen,

and it was resolved to engrave and set up publicly his grant of citizenship. When the Emperor Caesar Hadrian was an archon for the second time, when Iulius Hylas and Soteros, son of Soteros were councilors.

The diction of the two dating formulae and specifications of bestowed honours differ, ultimately proving that the Delphic honorific habit did not - and in fact did not need to - codify the formulae of decrees.

5) Several types of surviving enactment formulae suggest the use of different procedures. ${ }^{62}$ In Delphi, the most commonly attested kind of enactment formula is the non-probouleumatic formula: $\varepsilon^{\prime} \delta \circ \xi \varepsilon \tau \hat{\alpha} \iota \pi \dot{o} \lambda \varepsilon l \tau \hat{\omega} \nu \Delta \varepsilon \lambda \varphi \hat{\omega} \nu /$ it was resolved by the polis of the Delphians' ${ }^{63}$ Through the entire Hellenistic period up to the late first century $\mathrm{CE}$, the assembly was the only civic body

62 Larfeld 1914, 333; Rhodes and Lewis 1997, 4; McLean 2002, 222-223.

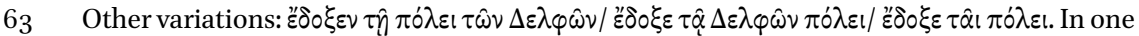
decree from the mid-first century $\mathrm{CE}$, the form [ $\left[\varepsilon_{\delta} \delta \xi \xi \varepsilon \nu \hat{\eta} \xi \varkappa \varkappa\right] \lambda \eta \sigma i \alpha /$ 'it was resolved by the assembly' is reconstructed ( $F d D$ 4.108). 
with legislative prerogatives at Delphi. The boule, which is attested in sources already in the fourth century BCE, probably only acted as an advisory board, as any bouleumatic or probouleumatic decrees are testified in this period. ${ }^{64}$ This situation changed in the late first century $\mathrm{CE}$, as thirteen documents reveal legislative activity of the boule. ${ }^{65}$ The legislative activity of the boule, the bestowal of bouleuteia as a new privilege, ${ }^{66}$ and the presentation of bouleutai as an upper echelon within the elite all point to the increasing role of the council within the civic structures and the gradual oligarchisation of the Roman Delphi. ${ }^{67}$ The transition to greater bouleutic powers marked not only an institutional and political shift but also a growing social divide between the regular citizenry ('people/demotai') and privileged members of the (noble) town council. ${ }^{68}$ By the end of the first century $\mathrm{CE}$, the gap between ordinary citizens and the upper class had deepened: the elites of the Delphic society by then consisted of highly-privileged damiourgo $i^{69}$ and bouleutai. ${ }^{70}$ Other Greek communities at that time, such as Athens, Olympia and the cities of Asia Minor, also saw affluent local families accumulate power and land and consequently dominate local civic councils. ${ }^{71}$

6) Usually, if the decree has a nonprobouleumatic enactment formula, then the motion will likewise follow the nonprobouleumatic pattern and men-

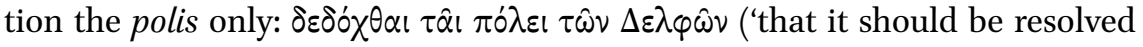

64 Grzesik 2018b, 123-124. See also Daux 1936, 427-43o; Roux 1970, 124-125; Roux 1976, 71-76; Salviat 1984, 743-76o; Rhodes and Lewis 1997, 135 .

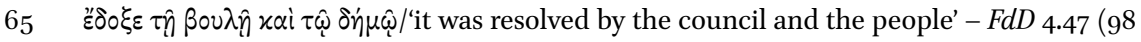

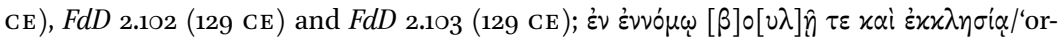
dained by the law of the council and the assembly' $-F d D 2.118$ (c. 200 CE); $\psi(\eta \varphi i \sigma \mu \alpha \tau \iota)$

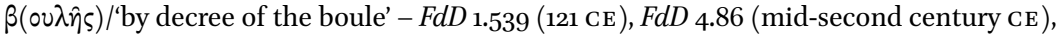
$F d D 4.272$ (mid-second century CE), FdD 4.272 (mid-second century CE), FdD 4.473 (c. 212 CE ), $F d D 1.200$ (imp.), $F d D 1.201$ (imp.), $F d D 1.214$ (imp.), $F d D 1.215$ (imp.).

66 From the end of the first century CE onwards, 42 honorific decrees confer bouleuteia as a new privilege, granting individuals a councilor's seat and a membership of the ruling class.

67 Grzesik 2018b, 123. See also Ferrary and Rousset 1998, 277-342.

68 Quass 1993, 389. See also Pleket 1998, 204-216 and Zuiderhoek 20o9, 53-70 and 61.

69 For damiourgoi at Delphi, see Vatin 1961, 236-255; Vatin 1970a, 259-263; Ferrary and Rousset 1998, 297-299; Hamon 2009, 373-378; Grzesik 2018b, 117-131. For damiourgoi in other Greek poleis, see Veligianni-Terzi 1977, 51-55 and 9o-96; Zoumbaki 2001, 90-95.

70 Ferrary and Rousset 1998, 277-342. Bouleutai as a separate upper class are also attested in Sillyon in Pamphylia (IGR III 800 and 801) and Poglia in Pisidia (IGR III 4O9). Sartre 1991, 141-142. See Chapter 2.1.2.

71 On Roman Athens, see Geagan 1967, 32-61; Woloch 1969, 503-510. On Roman Olympia, see Zoumbaki 2001, 65; on Asia Minor and Sillyon, IGR III, 800 and 801; on Knidos, SGDI 3549; on Argos, $S E G$ 11.314. Vatin 1961, 237; Quass 1993, 349; Ferrary 1987-1989, 203-216; Zuiderhoek 2009, 53-70. 
by the polis of the Delphians') + infinitive. ${ }^{72}$ The Delphic full decrees have a variety of infinitives to follow the motion, the most commonly used of

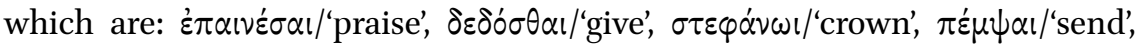

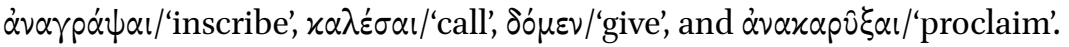

7) The motivation clause was a sort of justification of granted gifts, whose task was to exhibit the positive deeds of the honorand which motivated the privileges delivered by the assembly. ${ }^{73}$ Regrettably, the formulaic and rigid language of Delphic decrees often concealed the actual deed that was being rewarded and thus the link between the deed and the reward. In many full decrees and many more abbreviated decrees, no indication whatsoever existed about what the honorand had done to merit the honour. In a sample of over 200 Delphic full decrees, the following terms describe commendable qualities of the honorands (in descending order of frequency): evंvoos/'well-disposed',

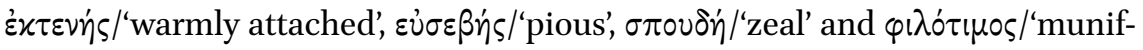
icent'. Honorands who made contributions to the city during a temporary stay

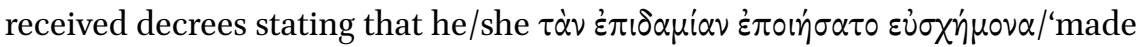

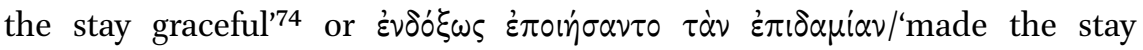
notable. ${ }^{\prime 5}$ Furthermore, $x \alpha \lambda \circ x \dot{\alpha} \gamma \alpha \theta i \alpha /$ 'nobleness' appears in many imperial period decrees as a desirable feature. ${ }^{76}$

The above-mentioned characteristics given in the motivation clause do not comprehensively describe the activities of honorands which led to the bestowal of Delphic honours. Some have attempted to reconstruct missing motivations: for example, Marek opted to read stories into missing decree passages in a way that conjectured the honorands' awards from their professions. ${ }^{77}$ In his view, a doctor must have served the city through a medical service and an artist must have given an artistic performance. Nonetheless, his approach was challenged on a number of grounds by other scholars as potentially misleading. ${ }^{78}$ For example, Constantakopoulou argued that there was no such a thing as a

72 Rhodes and Lewis 1997, 5; McLean 2002, 223-224. Nawotka (2014, 29-30), however, provides examples of Milesian decrees in which the combinations of theses formulae are attested.

73 Gengler 2017, 38-39.

$74 \quad F d D 2.89$.

$75 F d D$ 2.20. Wörrle 1995, 241-25o; Chankowski 2005, 196. See also Mack $(2015,32-39)$ on the characteristics of the proxenos-paradigm.

76 E.g. $F d D 3.129$ (20-75 CE), FdD 4.61 (75-10O CE), FdD 4.94 (138-161 CE), FdD 4.96 (imp.). The earliest attestation of $x \alpha \lambda \circ x_{\alpha} \gamma \alpha \theta_{i} \alpha$ comes from the decree dated to $180 / 179$ BCE ( $F d D$ 3.383). For 'philanthrophia' as a virtue in the late Hellenistic period, see Gray 2012, 137-162.

77 Marek 1984, 335-385.

78 Mack 2015, 59-65; Constantakopoulou 2017, 136-137. 
single motivation for the award of honours; a doctor could have professional, commercial, personal or social links with Delphi and could contribute to the community in a number of ways. Hence, Marek's assumptions oversimplify and distort the multi-faceted relations between the city and the honorand. ${ }^{79}$ Keeping Constantakopoulou's points in mind, I will focus only on those Delphic decrees that openly inform us about the commendable deeds of the honorand that the Delphic polis repaid in kind with granted honours.

Among decrees that specify the honorands' contributions in the motivation clause, the most numerous and diverse category includes artists, poets and musicians that came to Delphi either to participate in one of its many festivals or to perform independently for the community. ${ }^{80}$ The motivations reveal that Athanadas, son of Zopyros came to take part in the Soteria festival, ${ }^{81}$ a lyric poet from Thebes composed a prosodion, a paian and a hymn for the festival of Theoxenia, ${ }^{82}$ and an unknown artist obtained privileges after participating in the Pythian Games. ${ }^{83}$ In addition to artists, the Delphians conferred privileges upon many 'men of letters', including grammarians, public speakers and teachers. ${ }^{84}$ For example, Androtimos, son of Dexion from Karyneia received a standard package of Delphic honours in 134 BCE for teaching children. ${ }^{85}$

Other commendable acts mentioned in the motivation clauses concern the settlement of different types of disputes at Delphi. In nine cases, foreign judges were invited to settle unspecified conflicts, ${ }^{86}$ while two other decrees from c. 18 о вСE reward judges for solving a dispute between Delphi and Amphissa over the holy precinct and its borders. ${ }^{87}$ Two additional texts of $156 / 5$ BCE and 131/о BCE commend judges for resolving the dispute between the Delphians and the citizens of Lokris. ${ }^{88}$

Four decrees of 207/6 BCE reveal other motives for receiving Delphic honours. In these cases, all citizens of Messenia and four commanders of the

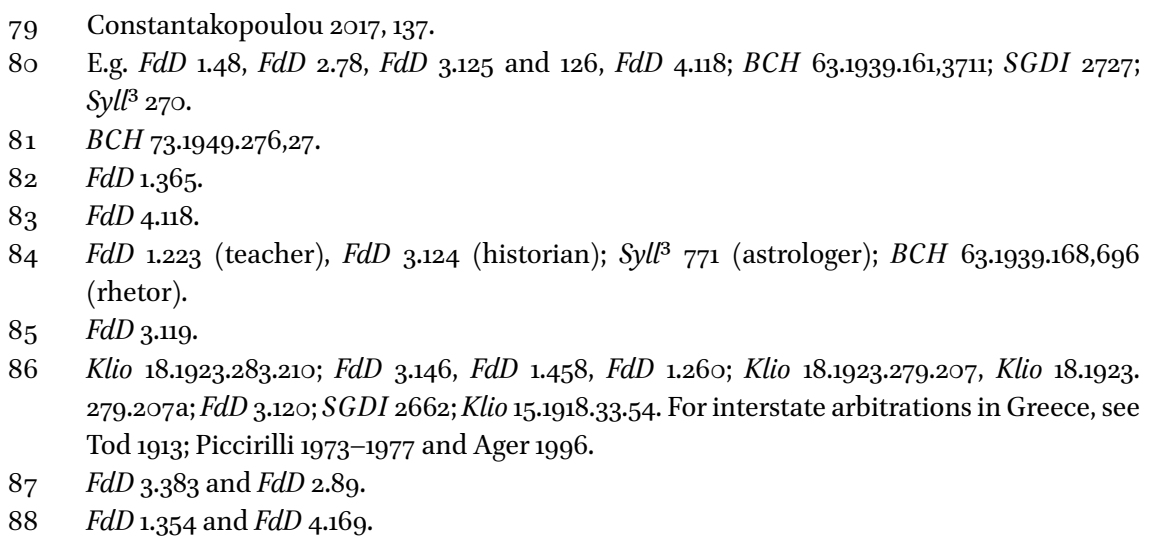


Messenian army were granted Delphic privileges for protecting the sanctuary of Apollo during the First Macedonian War. ${ }^{89}$

Sometimes, Delphic decrees rewarded Hellenistic kings for their specific contributions to the polis. For example, king Nikomedes III of Bithynia donated thirty slaves who were subsequently assigned to various tasks at Delphi. ${ }^{90}$ Another group of decrees, engraved either on the pillar of Eumenes II or on the statue base of Attalos II, celebrate deeds of these Attalid monarchs. Emumenes II provided Delphi with grain, sent workers to supervise the renovation of the theatre and donated a generous sum of money.91 His father Attalos II also contributed funds to be used for educating children (18,ooo drachmas) and for celebrating a new festival in his honour, the Attaleia (3,00o drachmas).$^{92}$

Among numerous Delphic decrees granted to public officials, only a few reveal the exact reasons for bestowing honours. One decree of $269 / 8$ в в с con-

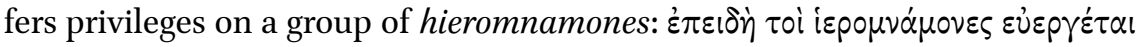

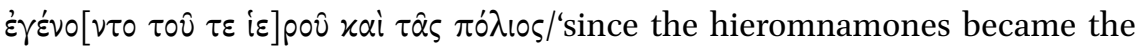
benefactors of the sanctuary and the city'; their euergetic deeds, however, remain unspecified. In contrast, a decree for Philinos, son of Philainetos from Miletos, reveals his civic contributions. Having acted as a Delphic proxenos and theorodokos at the beginning of the third century вСЕ, Philinos was granted a crown and proedria for hosting Delphic theoroi. ${ }^{93}$

There are only two examples of Delphic decrees voted for Delphians, both of which fortunately provide a detailed motivation clause. ${ }^{94}$ In the late first century CE a gymnasiarch Archelaos, son of Hyginos provided oil to the city while in office. ${ }^{95}$ The second citizen of Delphi praised by his own community performed such outstanding deeds that the city decreed upon him the title of a local hero. The only individual ever to receive this honour at Delphi, Memmios Neikandros beautified the city by organising the Pythian Games while he served as a secretary and xystarches ${ }^{96}$ and embellished Delphi with other

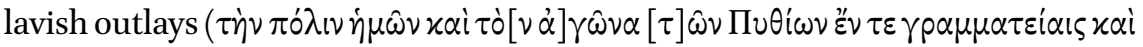

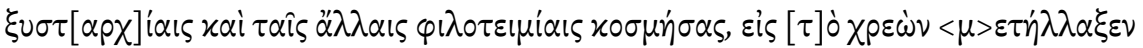
1. 4-7/adorned our city and the Pythian Games, and throughout all of his

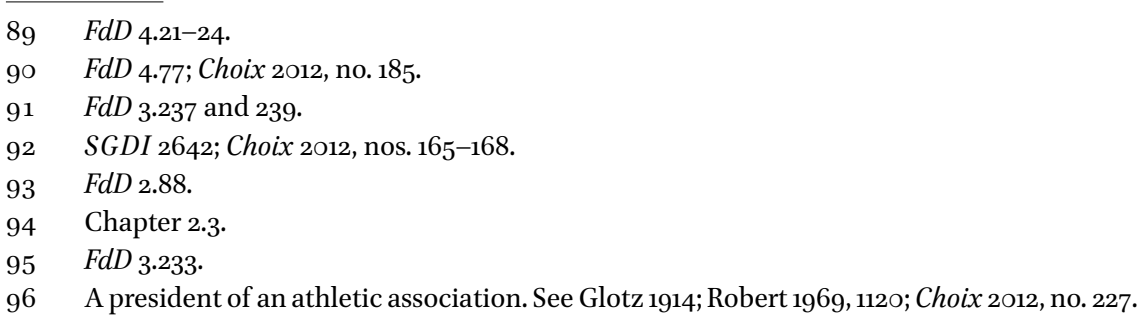


honorary pursuits, fulfilled his destiny'). It follows that these extraordinary contributions demanded an answer in kind - only the hero worship of the honorand could suffice. ${ }^{97}$

8) The text of a decree usually ended with closing formulae which offered supplementary information on (a) the erection of the decree and the name of the official responsible for the whole process, ${ }^{98}(\mathrm{~b})$ the place where the text of the decree should be inscribed; and (c) directions to send the copy of the decree to the honorand's hometown..$^{99}$ These closing formulae appear frequently in documents dated to 200-100 вСE: out of 31 Delphic decrees bearing the publication clause, 21 decrees date to the second century вСЕ (Table 6). Among the most commonly attested phrases describing the placement of decrees, one

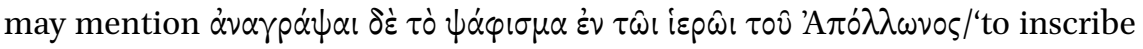

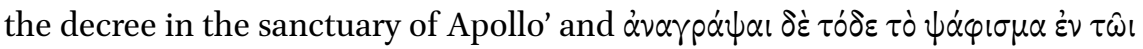

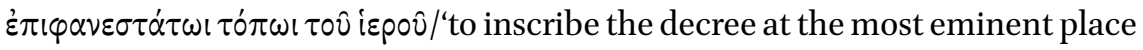

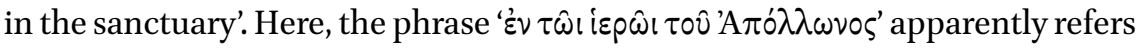
to the entire temenos, and not just to the temple itself, as decrees containing this specific clause hung on many buildings located within the peribolos. ${ }^{100}$ Occasionally, publication clauses name the public officials responsible for erecting the decree (an archon or an epimeletes) ${ }^{101}$ or record that a copy of the decree was sent to the honorand's hometown. ${ }^{102}$ Three texts of Delphic decrees specify the future location of the inscription: respectively, the Treasury

97 Grzesik 2015, 281-285.

98 Alternatively, it could name the current Delphic bouleutai (FdD 2.134c), the archon (SGDI 2662, SGDI 2652; Syll ${ }^{3} 6 \circ 8$ ), the secretary of the boule ( $F d D 2.89$ ), or, rarely, epimeletai ( $F d D$ 4.161) and epidamiourgoi ( $F d D$ 3.125).

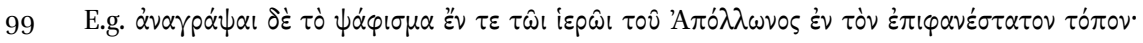

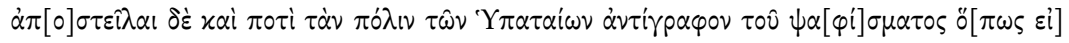
$\delta \hat{\omega} \nu \tau \iota \tau \dot{\alpha} \delta \varepsilon \delta \circ \gamma \mu \varepsilon \dot{v} \alpha \tau \hat{\alpha} \pi \dot{c} \lambda \varepsilon \varepsilon /$ 'to inscribe the decree in the most eminent place in the sanctuary of Apollo, to send the copy of the decree to the city of Hypata in order to inform about the decision of the city' $(F d D 1.260)$.

100 Syll ${ }^{3}$ 604: on the polygonal wall; $F d D$ 1.26o: at the Treasury of the Siphnians; $F d D$ 1.365: at the Treasury of the Thebans; $F d D$ 3.118: on the statue base in front of the Athenian stoa; $F d D$ 3.147: on the exedra near the aire; $F d D$ 4.47: on the monument of Aemilius Paullus.

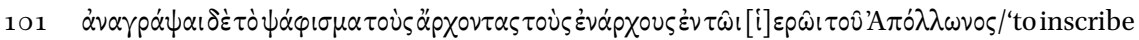

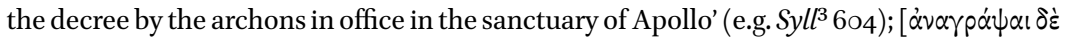

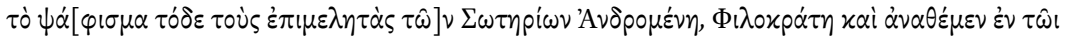

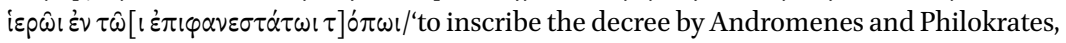
the epimeletai of the Soteria festival, and to set it in the most eminent place' ( $F d D$ 4.161).

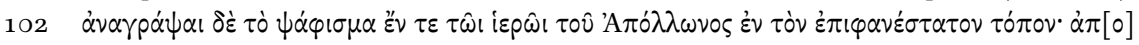

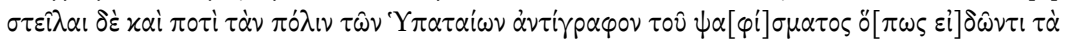

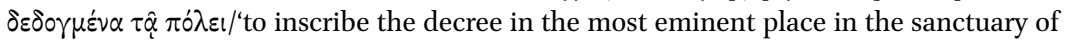
Apollo, to send the copy of the decree to the city of Hypata in order to inform about the decision of the city' (e.g. $F d D$ 1.26o). 
TABLE 6 The number of Delphic decrees with publication clauses

\begin{tabular}{|c|c|c|}
\hline 4th century вСЕ & o & \\
\hline 3rd century вСЕ & $\begin{array}{l}1+1(3 \mathrm{rd} / 2 \mathrm{nd} \\
\text { centuries BCE })\end{array}$ & $F d D 4_{4.153,} F d D 1.308$ \\
\hline 2nd century вСE & 21 & $\begin{array}{l}\text { SGDI 2662; Syll 6o4, Syll 689; Klio } \\
\text { 18.1923.278.207, Klio 18.1923.279.207a, Klio } \\
\text { 18.1923.286.213; FdD 1.26o, FdD 1.365, FdD 2.89, } \\
\text { FdD 2.92, FdD 3.118, FdD 3.120, FdD 3.125, FdD } \\
\text { 3.147, FdD 3.241, FdD 3.242, FdD 3.383, FdD 4.52 } \\
\text { FdD 4.65, FdD 4.161, FdD 4.171 }\end{array}$ \\
\hline 1 st century BCE & 5 & $\begin{array}{l}\operatorname{Syll}^{3} 737 ; F d D 3 \cdot 384, F d D 4.56, F d D 4.57, F d D \\
4 \cdot 77\end{array}$ \\
\hline imperial period & 2 & $F d D 4.47, F d D 4.59$ \\
\hline Undated & 1 & $F d D 3.142$ \\
\hline Total & 31 & \\
\hline
\end{tabular}

of the Athenians, ${ }^{103}$ the base of the Rhodian dedication, ${ }^{104}$ and the base of a statue of Prusias II onto which the decree for Nikomedes III, the king of Bithynia, was engraved. ${ }^{105}$

The Delphic full decrees of the second century вСE surpassed all those of both the preceding and following times in their length and complexity, employing all optional elements of the Delphic honorific formula. This allows us to conclude that the flourishing of the Delphic publication habit was gradual. Although the Delphic decree tradition first began to develop at the beginning of the fourth century ВСЕ and flourished in the third century ВСЕ, only in the second century BCE did Delphi witness the formulation of the most elaborate pattern of decrees. In turn, after the domination of Rome, the Delphians

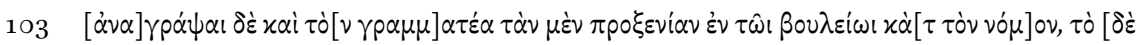

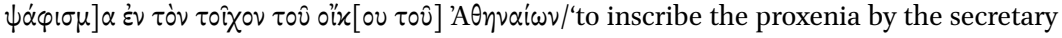
in the council house according to the law and the decree upon the wall of the Treasury of the Athenians' ( $F d D$ 2.89).

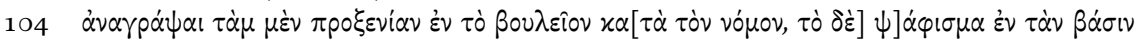

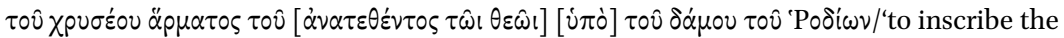
proxenia in the council house according to the law and the decree on the base of the golden chariot dedicated to the god by the people of the Rhodians' ( $F d D 3.383)$.

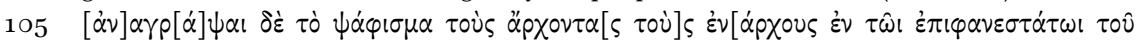

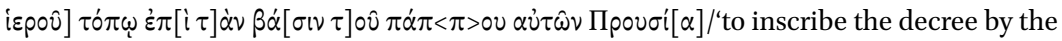
archons in office in the most eminent place in the sanctuary, on the base of the statue of his grandfather Prusias' ( $F d D$ 4.77). 
re-defined and simplified their long-established epigraphical habit, shortening and homogenising the texts of their decrees.

Having discussed the Hellenistic decree habit of Delphi, we may now proceed to compare Hellenistic decrees with their Roman-era equivalents. First, the Roman-era abbreviated decrees testify to changes in the appeal of particular decree types. The standard Hellenistic package of honours granted within Delphic abbreviated decrees (proxenia, promanteia, proedria, prodikia, asylia and ateleia) experienced a sharp drop in popularity under the Roman administration, whereas citizenship grants and bouleuteia became the most desirable honours. This shift required the modification of the verb used in the decree

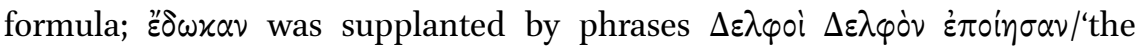

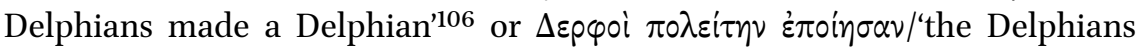
made a citizen'.107 Accordingly, the verbal alterations enforced shifts in the case of the nouns, with honorand names now rendered in the accusative. Second, the standard pattern of Delphic full decrees also evolved in the Roman imperial period. The bulk of Hellenistic decrees from Delphi includes the following

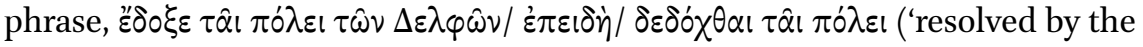
city of the Delphians/ since/ that is should be resolved by the city') with the dating formula affixed at the beginning or at the end:

$F d D 2.91$ (167 вСЕ)

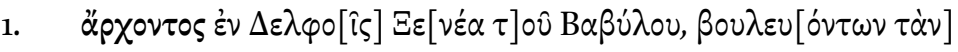

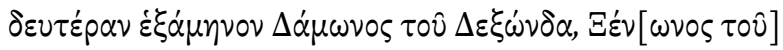

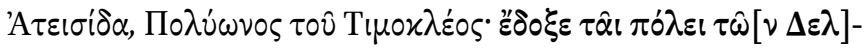

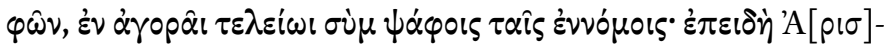

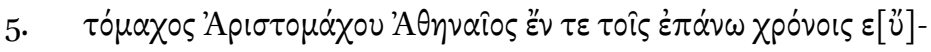

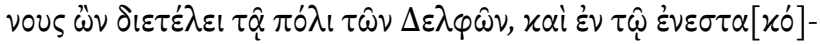

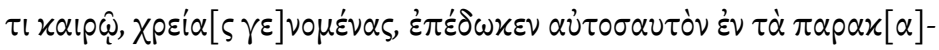

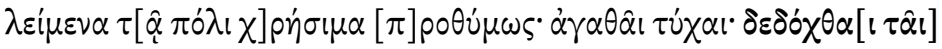

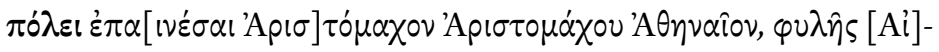

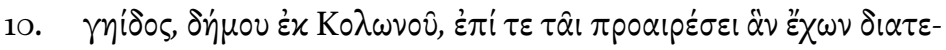

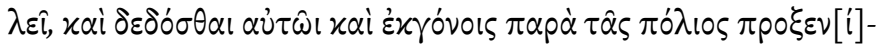

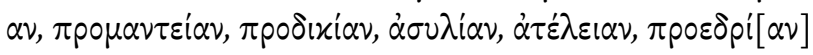

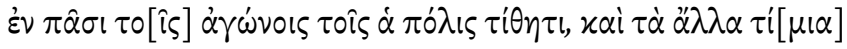

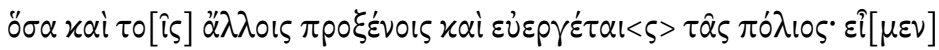

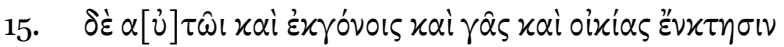

$106 \quad$ E.g. $F d D$ 1.199, $F d D$ 1.242, $F d D 2.101$.

$107 \quad F d D 1.238$. 
When Xeneas, son of Baboulos was archon in Delphi,

Damon, son of Dexondas, Xenon, son of Ateisidas and Polyon, son of Timokles were councillors in the second semester.

It was resolved by the city of the Delphians in a fully constituted agora, with the number of votes required by laws.

Since Aristomachos, son of Aristomachos from Athens

in former times was well-disposed towards the city of the Delphians, he devoted himself to the city in useful matters when it was needed.

For good fortune.

It should be resolved by the city to praise Aristomachos, son of Aristomachos an Athenian from the phyle Aigeis, deme Kolonos, for his constant attitude, and to grant him and his descendants proxenia, promanteia, prodikia, asylia, ateleia, proedria in all contests run by the city,

and he is to have everything else that is given to other proxenoi and benefactors.

To grant him and his descendant the right to acquire land and house.

From the mid-first century BCE onwards, the decrees changed to reflect the new socio-political situation. Texts of Delphic full pattern decrees tended to become shorter and parallel one another with very little variation. The additional elements were limited to the minimum; the manner of inscribing the name of the proposer of the motion was modified sometime in the period $55^{-25}$ BCE, while texts rendered commendable qualities of honorands in the prevalent Roman fashion. Finally, the Roman-era enactment formula highlighted the increasing role of the Delphic boule:
$F d D 2.103$ (129 CE)
1. $\quad \theta \varepsilon o ́ \varsigma \cdot \tau u ́ x \alpha \alpha \dot{\alpha} \gamma \alpha \theta \dot{\alpha}$. ह̀v $[\Delta \varepsilon] \lambda \varphi \circ \hat{\zeta}$

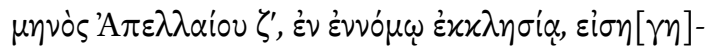

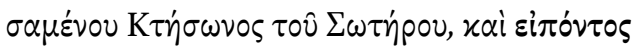

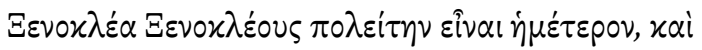

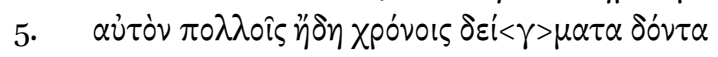

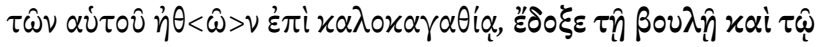

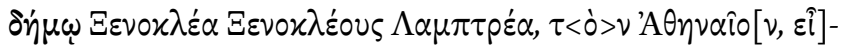

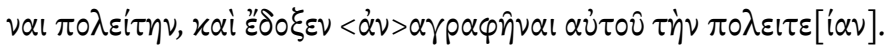

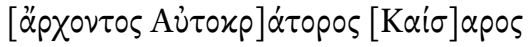

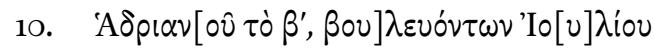

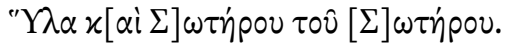


God. Good fortune

In Delphi, in the sixth day of the month Apellaios, in a legitimate assembly, when Kteson, son of Soteros, proposed and said that

Xenokles, son of Xenokles should be our fellow citizen

and that many times he has already given exhibitions of his leaning toward nobleness.

It was resolved by the council and the people

that Xenokles, son of Xenokles an Athenian from the deme Lamptrai is citizen,

and it was resolved to engrave and set up publicly his grant of citizenship. When the Emperor Caesar Hadrian was an archon for the second time, when Iulius Hylas and Soteros, son of Soteros were councilors.

\subsection{Tituli Honorarii ${ }^{108}$}

Formulae of the next category of Delphic honorific documents, tituli honorarii, most frequently consist of the name(s) of the dedicator(s) (in the nominative case), and the name(s) of the person(s) commemorated (in the accusative case). Many of the Delphic tituli honorarii combine dedicatory and honorific inscriptions, whilst nearly half of them include votive formulae at the end, i.e. the name of a divinity (in the dative case) receiving the statue (typically this is Apollo). ${ }^{109}$ Other occasionally included elements are sculptors' signatures, ${ }^{110}$ or information about who supervised the work ${ }^{111}$ or bore the costs of erection of the statue. ${ }^{112}$

What is remarkable in the case of Delphic honorific inscriptions in comparison with tituli honorarii from other regions is the inscribed presence of the

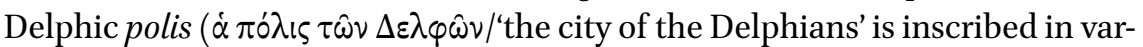
ious ways) as the ultimate authority for most of the honorific images granted by the civic institutions, a formulation which remained standard for over 600 years. One possible parallel surfaces in honorific inscriptions from Olympia,

\footnotetext{
108 This is a summary of the definition of Delphic tituli honorarii from my article published in 2019 in Historia. See Grzesik 2019, 201-202.

109 E.g. $F d D$ 1.526, $F d D$ 3.74, $F d D$ 4.264[2]; $B C H 49.1925 .83$.

110 E.g. $B C H 64 / 65.1940 / 1.65, B C H$ 68/69.1944/5.113.D; $F d D$ 1.524. For sculptors' signatures, see Marcadé 1953-1957, 2 vols.; Geagan 2011, 272-284; Kansteiner, Hallof, Lehmann et al. 2014, 5 vols.; Hurwit 2015 .

111 E.g. FdD 4.274.

112 E.g. $B C H$ 70.1946.254.8; $C I D$ 4.149. See Fejfer 2008, 30; Geagan 2011, 141.
} 


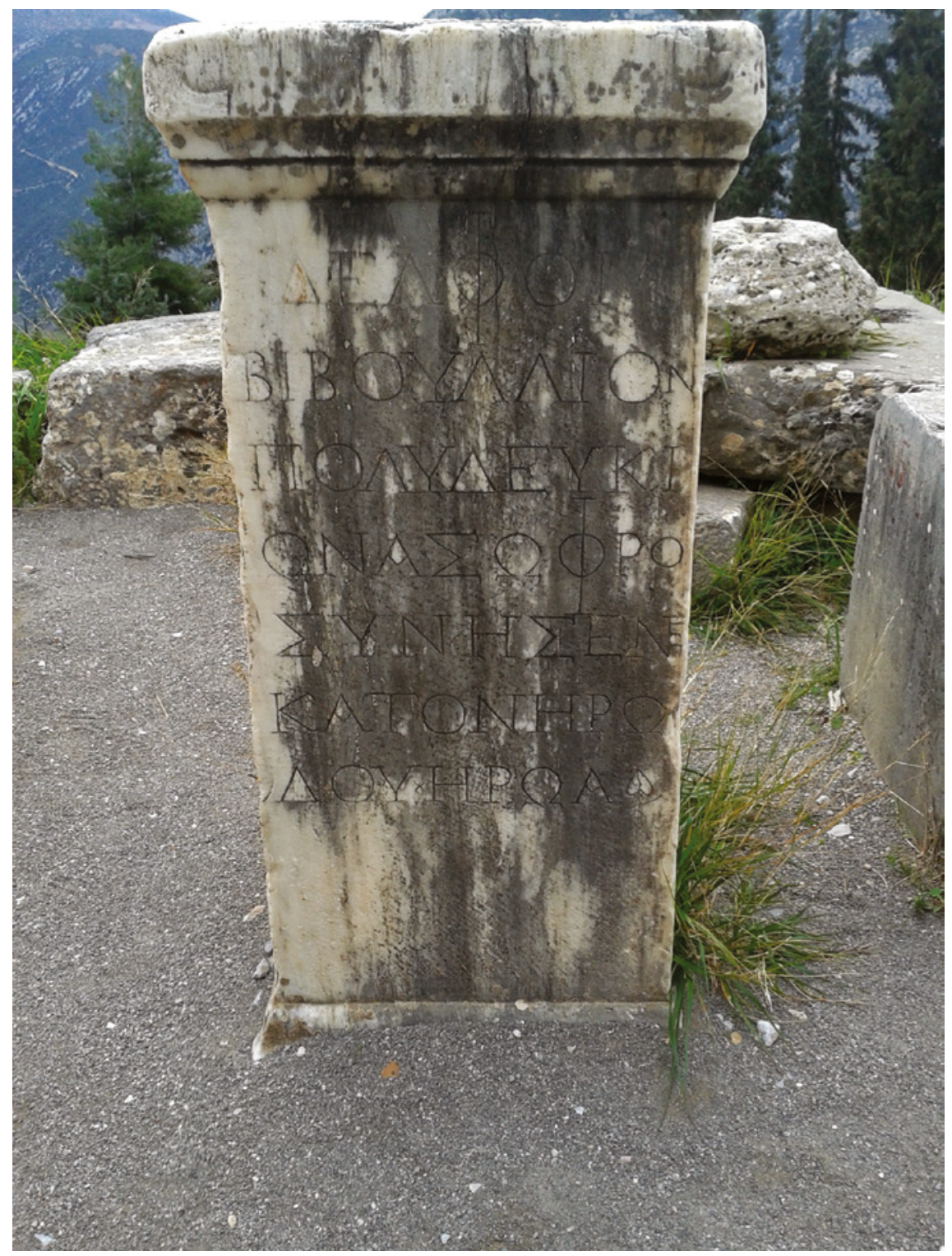

рното 3 Titulus honorarius for Vibullius Polydeukion, son of Herodes Atticus. $\Delta \varepsilon \lambda \varphi{ }^{\circ}$

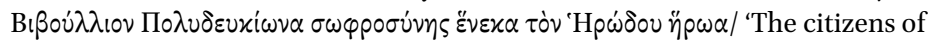
Delphi (set up a statue of) Vibullius Polydeukion, son of Herodes, for his wisdom', $F d D$ 3.74. (Archaeological site of Delphi. The monument is under the protection of the Ephorate of Antiquities of Phocis.)

(C) THE HELLENIC MINISTRY OF CULTURE AND SPORTS/ ARCHAEOLOGICAL RESOURCES FUND 
where the main authority which gave the award of the honorific inscription was the city of the Eleians ( $\dot{\eta} \pi \dot{\lambda} \lambda\left(\varsigma \dot{\eta} \tau \omega \nu \mathrm{H} \lambda \varepsilon \dot{i}(\omega \nu) .{ }^{113}\right.$ In contrast, decrees from the majority of other Greek city states most frequently use the formula हैंठ

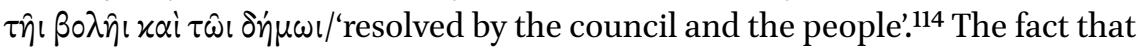
so many of the honorific statues raised at Delphi were also dedications to a god proves that the religious and civic contexts there constantly merged and mingled. Parallels for this may be found, among other places, at Samos and Delos, where honorific portraits were inscribed as dedications to Hera in the former and to Apollo alone or together with Artemis and Letos in the latter. ${ }^{115}$

\subsection{Conclusion}

This chapter considered in detail the formulae and idiosyncrasies of the language of honours used by the Delphians. In order to draw some general conclusions, it is necessary to return to the question posted in the introduction to this chapter: what was the language of honours used by the Delphians? Many features of the decrees' honorific diction separate Delphi from other poleis. The Delphic honorific habit enduringly employed concise and space-saving abbreviated decrees. Laconic, repetitive Delphic formulae stand in opposition to florid, sprawling documents and decrees from Athens and the cities of Asia Minor. ${ }^{116}$ The rigidity and severity of the Delphic honorific language comes to the forefront in the Delphic motivation clauses: even the deeds of Memmios Neikandros, which were so extraordinary that they made his fellow citizens grant him hero worship, were not described in detail in the decree's motivational clause. Of course, following Domingo Gygax's notion that euergetism had two faces (benefactions and rewards), one must admit that the material from Delphi often shows us rewards but not the benefactions that were being rewarded. But, nevertheless, the richness of the analysed sample (over a thousand preserved decrees) offers one a unique perspective on the Delphic honorific procedure. My analysis has also demonstrated that abbreviated Delphic decrees, although concise, still conveyed essential information on the honour granted - and thus fully merit their place within the Delphic honorific culture.

Notably, many features of the Delphic language of honours resemble those which is found in decrees issued in other communities. Both the Athenians

\footnotetext{
113 Zoumbaki 2001, 28-30.

114 Rhodes and Lewis 1997.

115 E.g. Samos 189.

116 For benefactions listed in decrees from Asia Minor, see Zuiderhoek 2009.
} 
and the Delphians called their decrees psephismata. As one found in the Peloponnese, at Delphi documents only rarely name proposers of motions. Inscribing decrees on building surfaces occurred not only in Delphi but also in smaller poleis such as Arkesine on Amorgos, in Megara or on Siphnos. The abbreviated form of decrees appears in documents issued by the Delphians, the Aetolians, the citizens of Gonnoi in Thessaly, or in Olbia. Commendable qualities of honorands praised in motivation clauses both at Delphi and abroad show great similarities and demonstrate that the Greek honouring habit uniformly preferred the consistency of language to precise descriptions relating the honorands' actual deeds. ${ }^{117}$ Whilst allowing for local variations, the Delphic honorific idiom fed into and drew from the Panhellenic honorific convention, reflecting many of its global-trends.

117 Mack 2015, 32-33. 